\title{
Differential responses in growth and water relationship of Medicago sativa (L.) cv. Gabès and Astragalus gombiformis (Pom.) under water-limited conditions
}

\author{
M. Gorai*, A. Hachef and M. Neffati
}

\author{
Laboratoire d'Ecologie Pastorale, Institut des Régions Arides, Médenine 4119, Tunisia
}

\begin{abstract}
This study aims to compare the growth attributes and water relationship of two-forage legume plants: a crop plant, Medicago sativa (L.) cv. Gabès, and a wild plant, Astragalus gombiformis (Pom.), under drought-stress conditions. Water deficit stress was imposed at $40 \%$ and $70 \%$ of field capacity (FC) from 60 to 90 days after sowing, while the control pots were maintained at $100 \%$ FC throughout the period of entire growth. The results showed that the high potentialities of growth in both species were recorded for control plants. Water deficit reduced growth (whole plant biomass, leaf number, stem elongation rate and shoot relative growth rate) and decreased shoot/root ratio. After 30 days of water deficit stress, the leaf relative water content (RWC) and the water potential $\left(\Psi_{\mathrm{w}}\right)$ evolved in such a way and decreased significantly as water stress was intensified. The lowest level of transpiration rate of the most stressed plants may be explained by the lowering of leaf RWC. Under such conditions, the water use efficiency of wild plants was more pronounced than alfalfa plants. It can be concluded that A. gombiformis manifested the best morpho-physiological traits of adaptation to moisture stress when compared to $M$. sativa. This wild plant appears to be more tolerance to water stress than that cultivated, therefore a possibility of exploitation of this species.
\end{abstract}

Keywords: Astragalus gombiformis, drought, growth, Medicago sativa, water relations.

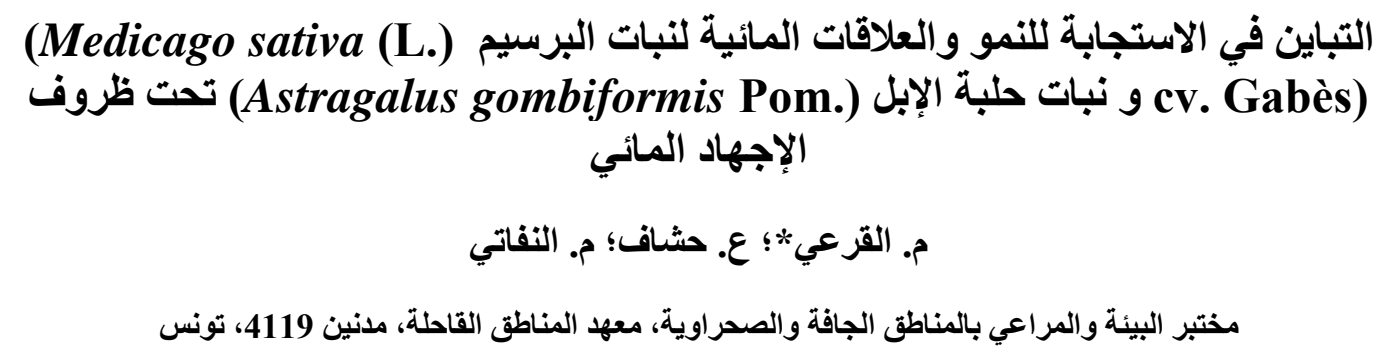

الملخص: تهدف هذه الدر اسة لمقارنة خصائص النمو و العلاقات المائية لنباتين ينتميان إلى العائلة البقولية العلفية، الأول مستأنس: Medicago sativa (L.) cv. Gabès

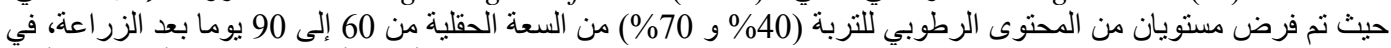

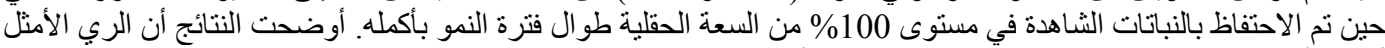

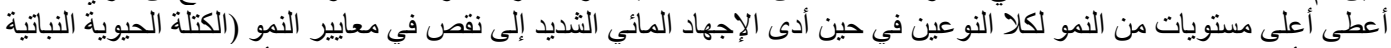

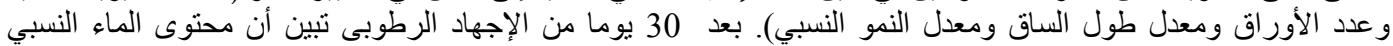

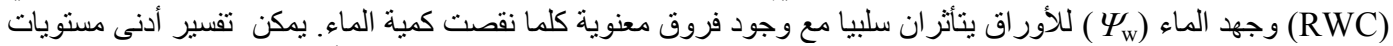

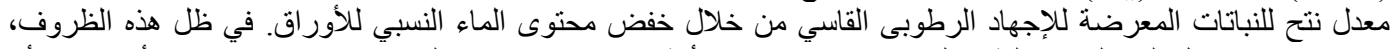

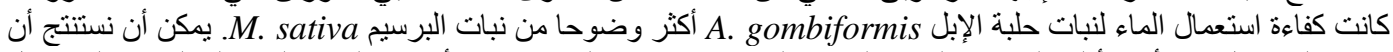

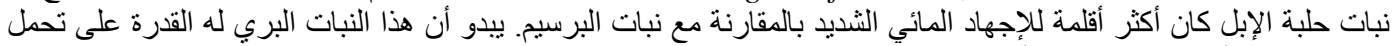

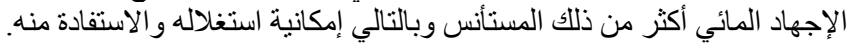

\footnotetext{
*Corresponding Author, Email: gorai.mustapha@yahoo.fr
} 


\section{Introduction}

Tunisia occupies an area of about $164,000 \mathrm{~km}^{2}\left(32-38^{\circ} \mathrm{N}, 7-12^{\circ} \mathrm{E}\right)$, three quarters of which are arid and desert regions (Le Houérou, 1959) characterised by low rainfall, high evapotranspiration, high temperature and desiccating winds. Among 2250 species that compose its vascular flora (Cuénod et al., 1954; Pottier-Alapetite, 1979, 1981; Le Houérou, 1995), 1630 species belong to the steppic zone (Le Houérou, 1995). One of the promising options for the use of this diversity is to use legumes that have multiple functions in the ecosystem. Several wild species are potentially interesting associated to their economic and ecological interests which they present, including Astragalus gombiformis (Pom.).

Astragalus gombiformis, a wild psammophytic species in the family of Fabaceae (Chaieb and Boukhris, 1998), is widely distributed in Tunisian arid zone (Porttier-Alapetite, 1979). It is a forage legume plant, well adapted to arid conditions, namely to sandy soils and widely consumed by the dromedary (Chaieb and Boukhris, 1998). Up till now there has been little experimental research with A. gombiformis, but knowledge about its growth and physiological attributes in response to moisture stress might be important characterizing this desert plant ecologically.

Furthermore, the water deficit, permanent or temporary, limited growth and distribution of the natural vegetation and the performance of plants more than other environmental factors The tolerance of plants to water limited conditions is a complex phenomenon that involves specific morphological and developmental mechanisms with physiological and biochemical change. This tolerance is observed at all the vegetable species, but its magnitude varies from a species to another. Plant water status and transpiration, while acting on the growth and development, may be involved in determining the yield of biomass and grain of species. Changes in water characteristics of a plant reflect its water status and its ability to incorporate water, particularly under drought stress (Radhouane, 2008). In dry conditions, the decrease in water potential $\left(\Psi_{\mathrm{w}}\right)$ of plants induces an important loss of leaf turgescence (Boyer, 1982; Sorrells et al., 2000). The maintenance of high water potential was associated to the ability of plants to take water from the soil and their capacity to limit water loss through transpiration (Turner, 1986). The wateruse efficiency (WUE) is a kind of trait that can contribute to crop productivity when water resources are scarce (Wright et al., 1994). Lowering the vapour pressure, air around the leaves increases the rate of transpiration (Angus and van Herwaarden, 2001). Moreover, the stomata are closed and there will be a lowering of the leaf $\Psi_{\mathrm{w}}$. Unless some compensation closure of stomata occurs, lower humidity will decrease the WUE (Hsiao et al., 2007).

Moisture stress is reflected by problems in agricultural and ecological levels. It is therefore important to search for plants adapted to drought and able to produce high biomass or grain yield under water deficit conditions. Understanding adaptive mechanisms to moisture stress is necessary to guide the search of cultivated species or varieties less demanding water. In addition, the study of physiological attributes altered by water deficit for understanding the behavior of species able to develop in arid and semi-arid regions and to consider a better rehabilitation of lands by these species as well as an optimal valorization for different purposes of plants subjected to this constraint. This work aims to compare the growth and water relationships of two-forage legume plants: a crop plant, Medicago sativa (L.) cv. Gabès (alfalfa), and a wild plant, $A$. gombiformis (Pom.), largely widespread in the arid and desert regions of Tunisia, 
under drought-stress conditions. We tried to identify possible morpho-physiological criteria for assessing the degree of tolerance of A. gombiformis under water limitation when compared to the alfalfa, for its assay of introduction into the farming techniques in arid and semi-arid regions.

\section{Material and methods \\ Plant material and growth conditions}

Seeds of both species were provided by the seed bank of the Institut des Régions Arides (IRA), Médenine, Tunisia. The experiments were conducted at the Laboratoire d'Ecologie Pastorale, IRA, Médenine, Tunisia. Seeds were surface sterilized in $0.58 \%$ sodium hypochlorite solution for one minute with frequent shaking and subsequently washed with tap water. The experiments were carried out in plastic pots by gravimetric method. The weight of the empty pots (1-L) were recorded and filled with a uniform soil mixture containing sandy soil: organic matter (terreaux professionnels Agrofino) in 1/3:2/3 ratio. Pot culture studies were conducted to measure the WUE and other related parameters more precisely under the different moisture levels. Five seeds were planted in each pot and watered to $\mathrm{FC}$ to facilitate germination. On the 30 days after emergence, the seedlings were thinned to one uniform plant per pot. Seedlings were grown in a growth chamber as follows: $25^{\circ} \mathrm{C} \pm 1{ }^{\circ} \mathrm{C}$ temperature, $40 \%$ day and $75 \%$ night relative humidity and $16 \mathrm{~h}$ light $/ 8 \mathrm{~h}$ dark regime, and $250 \mu \mathrm{mol} \mathrm{m}^{-2} \mathrm{~s}^{-1}$ photosynthetic active radiation (PAR).

\section{Water deficit treatment}

Individual plants presenting homogeneous development and size were selected for this study. The experiment was arranged in a completely random design (CRD) with four replicates for three water supply regimes: 100, 70 and 40\% FC. Treatments were imposed from the 60 to the 90 days. Water loss was determined by weighing the pots daily using an electronic weighing device. Regular weightings enabled to restore the moisture of soil with rain water at $40 \%, 70 \%$, and $100 \%$ FC. Each treatment pot was paired with a pot without a seedling that served as a control to correct soil evaporation when determining WUE.

\section{Measurements and calculations}

Plants were harvested at the beginning of the treatment (initial harvest) and after 15 and 30 days (final harvest) throughout each watering regime. The stem elongation rate (SER), was calculated as $\mathrm{SER}=\Delta \mathrm{L} / \Delta \mathrm{t}$, where $\Delta \mathrm{L}$ is the difference between final and initial length value an $\Delta \mathrm{t}$ is the duration of watering regime (Ramesh, 2000). Fresh weight (FW) and dry weight (DW) of shoots and roots of each plant (four per treatment) were determined after counting the leaf number (LN). The dry matter weights of plants were measured after oven drying at $60^{\circ} \mathrm{C}$ for $48 \mathrm{~h}$. The relative growth rate (RGR) based on shoot dry weight production, was calculated as $\mathrm{RGR}=[\mathrm{ln}$ $\left.\left(\mathrm{W}_{2}\right)-\ln \left(\mathrm{W}_{1}\right)\right] /\left(\mathrm{t}_{2}-\mathrm{t}_{1}\right)$, where $\mathrm{W}$ is the dry matter at the beginning $\left(\mathrm{W}_{1}\right)$ and the end $\left(\mathrm{W}_{2}\right)$ of the 15 and 30 days treatment period, and $\left(t_{2}-t_{1}\right)$ is the duration of this period (Hunt, 1990).

Leaf relative water content (RWC) was estimated by recording the turgid weight (TW) of fresh leaf samples by keeping them in distilled water in Petri dishes for $24 \mathrm{~h}$ at $4^{\circ} \mathrm{C}$ in darkness, followed by oven dry for $48 \mathrm{~h}$ at $60^{\circ} \mathrm{C}$ for dry weight measurement. Leaf RWC was calculated as RWC $(\%)=(\mathrm{FW}-$ $\mathrm{DW}) /(\mathrm{TW}-\mathrm{DW}) \times 100$ (Jeon et al., 2006). Leaf and stem $\Psi_{\mathrm{w}}$ were measured, respectively, for $A$. gombiformis and $M$. sativa using a pressure chamber (PMS Instrument Co., Corvallis, Oregon, USA), according to Sholander et al. (1965).

WUE for each seedling was determined by the ratio of dry mass production to water transpired during the 
experiment (Wu et al., 2008). The biomass accumulated during the treatment period (60 and 90 days) was computed as the difference in the initial and final dry matter and expressed as $g$ plant ${ }^{-1}$ for WUE calculation. While calculating the cumulative water transpired (CWT) during the experiment, evaporative loss from the pots was taken into account by subtracting the average amount of water loss from the control pots without plants from each watering treatment.

\section{Statistical analysis}

Statistical analyses, including test for homogeneity of variance, were analysed using SPSS for Windows, version 11.5. The experimental data were analysed with a oneway ANOVA to determine if significant differences were present among means. Duncan's Multiple Range Test (DMRT) was carried out to determine if significant $(P<$ $0.05)$ differences occurred between individual treatments.

\section{Results}

\section{Growth attributes}

In both species, the high potentialities of growth were recorded for control plants (Figure 1a). Among these species, A. gombiformis had a reduced dry matter. After 30 days of water deficit stress, the dry matter production of plants watered with $40 \% \mathrm{FC}$ decreased significantly by $51 \%$ and $41 \%$, as compared to control plants for M. sativa and A. gombiformis, respectively. The alfalfa was more sensitive to moisture stress than the wild species as indicated by the reduced LN at the end of experiment (Table 1). Thus, plants receiving a water regime of $100 \%$ FC have the highest number of leaves for $M$. sativa (94) and A. gombiformis (17). After 30 days of water deficit stress, the LN of $M$. sativa plants decreased as the stress was intensified, while A. gombiformis plants did not vary significantly, as compared to controls. Water deficit at $70 \%$ and $40 \%$ FC decreased significantly the shoot RGR and SER in both species when compared to controls (100\% FC) during 30 days of drought-stressed conditions (Table 1). Shoot/root dry matter ratio was significantly lower in both species subjected to water deficit stress than in controls (Figure 1b).
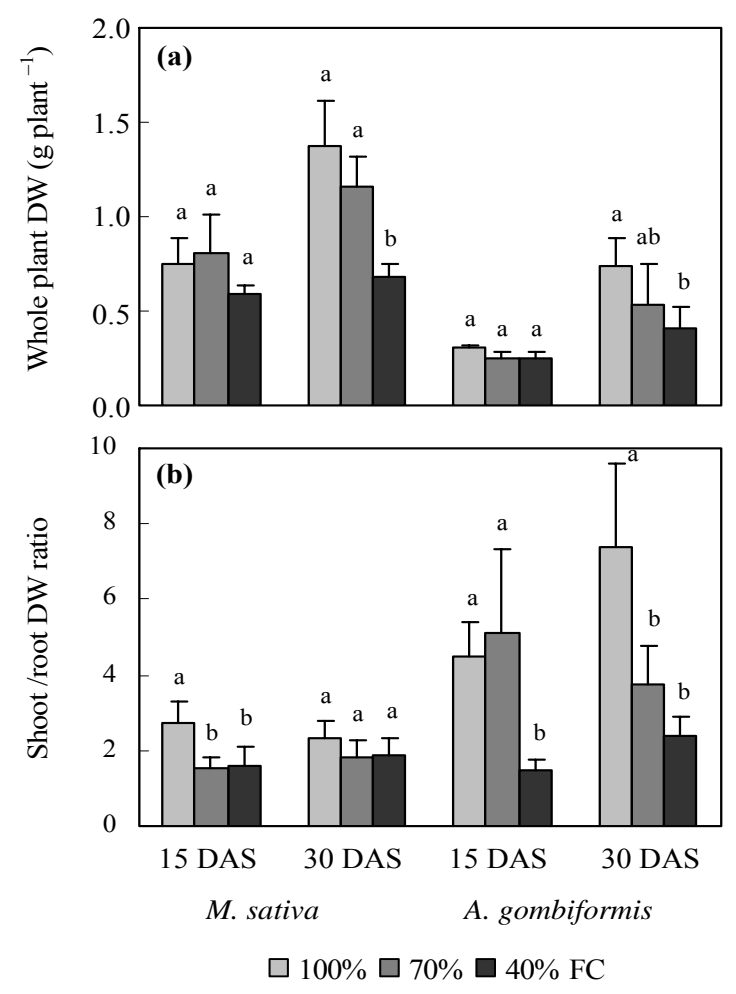

Figure 1. Changes in (a) whole plant dry weight (DW, g plant $^{-1}$ ) and (b) shoot/root DW ratio of Medicago sativa and Astragalus gombiformis when 2-month old plants were subjected for 15 and 30 days (DAS) to $100 \%$, $70 \%$ or $40 \%$ field capacity (FC). Different letters above bars are significantly different at the $P=0.05$ level for the given watering regime (mean $\pm 95 \%$ confidence limits, $n=4)$.

\section{Water relationships}

Figure $2 \mathrm{a}$ shows the changes in the leaf relative water content along with increase in water deficit stress. The leaf RWC decreased significantly in both species as water regime was intensified. This depressive effect was more pronounced with treatment duration. Water deficit at $40 \%$ FC decreased RWC on 30 days when compared to control reaching approximately $80 \%$ and $79 \%$ in $M$. sativa and A. gombiformis, respectively. The $\Psi_{\mathrm{w}}$ was significantly lower in plants subjected to water deficit stress than in controls (Figure 2b). 
Table 1. Leaf number (LN, plant $\left.{ }^{-1}\right)$, stem elongation rate (SER, $\mathrm{cm}^{-1}$ ), whole plant dry weight (DW, $\left.\mathrm{g} \mathrm{plant}^{-1}\right)$ and shoot relative growth rate $\left(\right.$ RGR, day $^{-1}$ ) of Medicago sativa and Astragalus gombiformis when 2-month old plants were subjected for 15 and 30 days to three moisture regimes $(100 \%, 70 \%$, and $40 \%$ FC).

\begin{tabular}{|c|c|c|c|c|c|c|}
\hline & \multicolumn{3}{|c|}{15 DAS } & \multicolumn{3}{|c|}{30 DAS } \\
\hline & $100 \%$ FC & $70 \%$ FC & $40 \%$ FC & $100 \%$ FC & $70 \%$ FC & $40 \%$ FC \\
\hline \multicolumn{7}{|l|}{ M. sativa } \\
\hline $\mathrm{LN}\left(\right.$ plant $\left.^{-1}\right)$ & $84 \pm 15.15 \mathrm{a}$ & $82 \pm 4.96 \mathrm{a}$ & $59 \pm 19.34 \mathrm{a}$ & $94 \pm 6.27 \mathrm{a}$ & $91 \pm 25.10 \mathrm{a}$ & $53 \pm 13.10 b$ \\
\hline $\operatorname{SER}\left(\mathrm{cm} \mathrm{j}^{-1}\right)$ & $0.117 \pm 0.011 \mathrm{a}$ & $0.065 \pm 0.022 b$ & $0.052 \pm 0.006 \mathrm{~b}$ & $0.138 \pm 0.043 \mathrm{a}$ & $0.058 \pm 0.030 \mathrm{~b}$ & $0.043 \pm 0.011 b$ \\
\hline Shoot RGR $\left(\right.$ day $\left.^{-1}\right)$ & $0.046 \pm 0.015 \mathrm{a}$ & $0.038 \pm 0.012 \mathrm{ab}$ & $0.019 \pm 0.009 b$ & $0.042 \pm 0.006 \mathrm{a}$ & $0.034 \pm 0.002 \mathrm{~b}$ & $0.016 \pm 0.003 \mathrm{c}$ \\
\hline \multicolumn{7}{|l|}{ A. gombiformis } \\
\hline $\mathrm{LN}\left(\right.$ plant $\left.^{-1}\right)$ & $11 \pm 1.67 \mathrm{a}$ & $11 \pm 1.67 \mathrm{a}$ & $13 \pm 1.13 \mathrm{a}$ & $17 \pm 2.93 \mathrm{a}$ & $16 \pm 3.49 \mathrm{a}$ & $15 \pm 0.49 \mathrm{a}$ \\
\hline $\operatorname{SER}\left(\mathrm{cm} \mathrm{j}^{-1}\right)$ & $0.143 \pm 0.077 \mathrm{a}$ & $0.113 \pm 0.023 \mathrm{a}$ & $0.080 \pm 0.025 \mathrm{a}$ & $0.208 \pm 0.082 \mathrm{a}$ & $0.182 \pm 0.100 \mathrm{a}$ & $0.133 \pm 0.054 \mathrm{a}$ \\
\hline Shoot RGR $\left(\right.$ day $\left.^{-1}\right)$ & $0.075 \pm 0.004 \mathrm{a}$ & $0.059 \pm 0.013 \mathrm{a}$ & $0.038 \pm 0.008 \mathrm{~b}$ & $0.069 \pm 0.007 \mathrm{a}$ & $0.052 \pm 0.014 \mathrm{ab}$ & $0.041 \pm 0.011 b$ \\
\hline
\end{tabular}

Means within a line followed by the same letter are not significantly different at the $P=0.05$ level for the given watering regime (mean $\pm 95 \%$ confidence limits, $n=4)$. 
Water deficit at $40 \%$ FC decreased the $\Psi_{\mathrm{w}}$ in both species reaching the most negative values. With the same watering regime, the $\Psi_{\mathrm{w}}$ attained $-1.9 \mathrm{MPa}$ and -1.4 MPa during 30 days of water deficit stress for $M$. sativa and A. gombiformis, respectively. The CWT level decreased in both species under drought-stress conditions (Figure 2c). Among the species, A. gombiformis showed a lower transpiration rate and it was $42.89 \%$ of that of the control plants. A higher level of transpiration rate occurred in $M$. sativa was $46.76 \%$ of that of the control plants after
30 days of watering regime with $40 \% \mathrm{FC}$. WUE levels of both species were inversely proportional to increase in drought stress and duration (Figure 2d). Water stress did not display differences in WUE in both species as compared to control plants. After 30 days of water deficit stress, the WUE of A. gombiformis plants increased as water stress intensified, while the WUE of $M$. sativa plants deceased. Among the species, A. gombiformis watered with $40 \%$ FC showed the highest values of WUE when compared to controls (100\% FC).
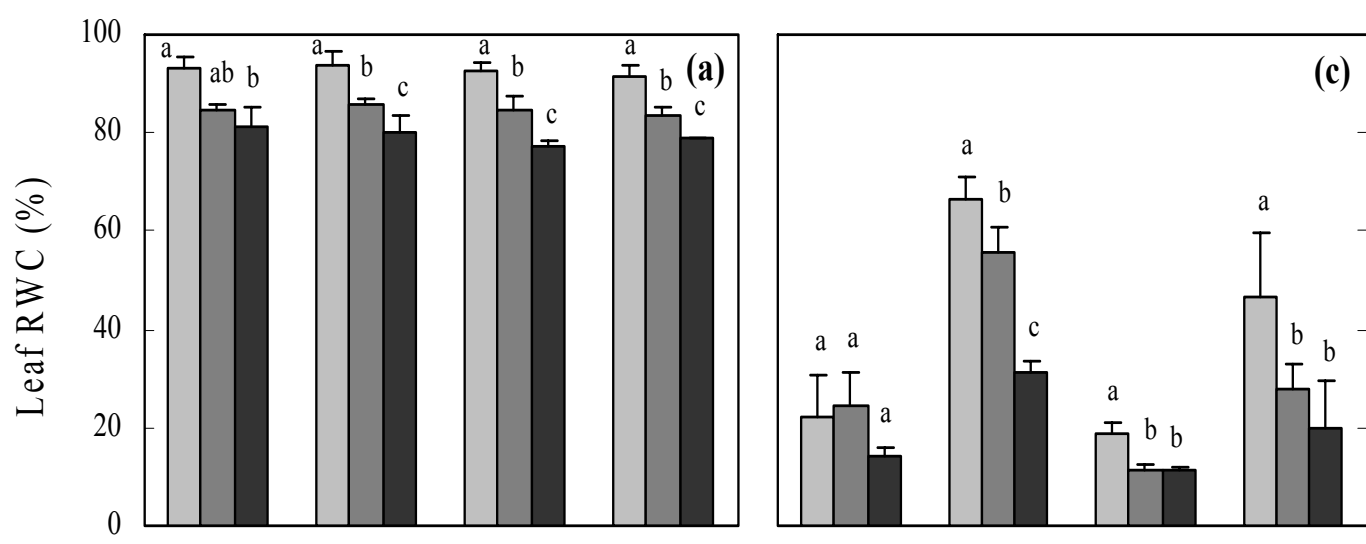

1.0
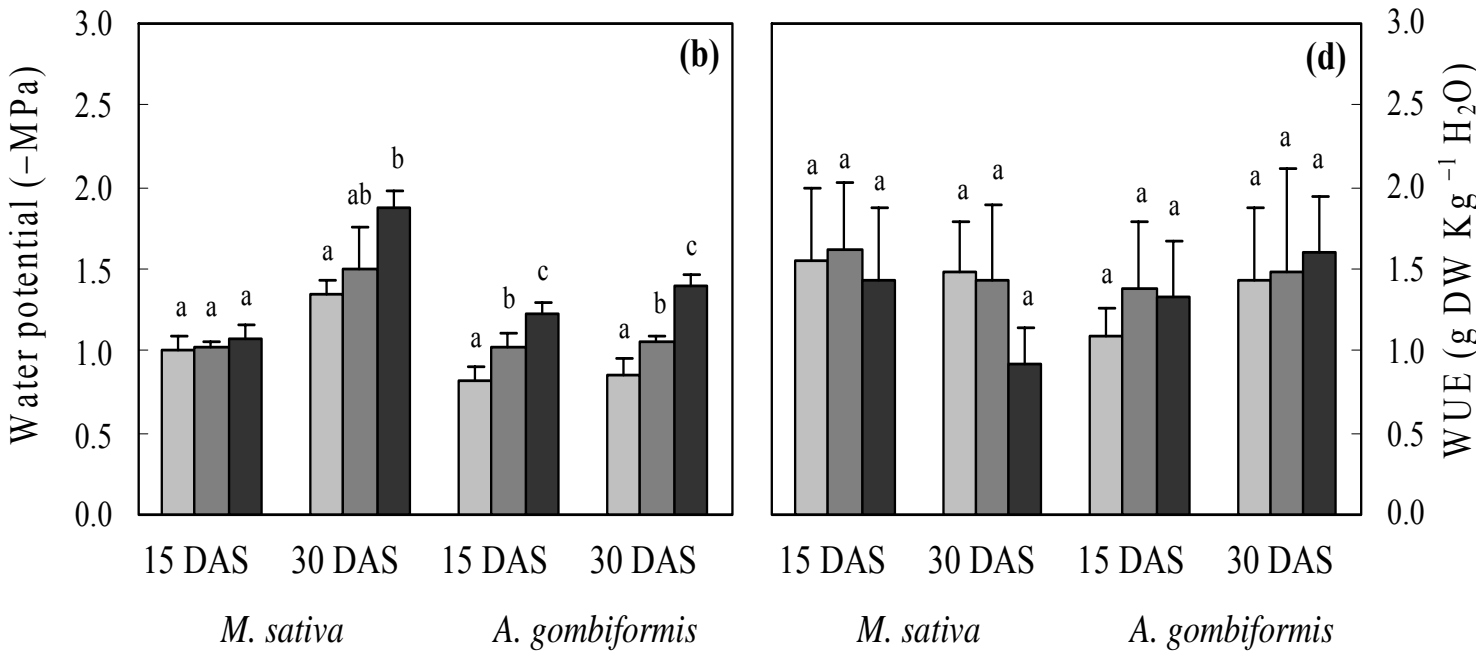

$\square 100 \% \square 70 \% \square 40 \% \mathrm{FC}$

Figure 2. Changes in (a) leaf relative water content (RWC, \%), (b) leaf or stem water potential $\left(\Psi_{\mathrm{w}}, \mathrm{MPa}\right),(\mathrm{c})$ cumulative water transpired $\left(\mathrm{CWT}, \mathrm{kg} \mathrm{plant}^{-1}\right)$ and (d) water use efficiency (WUE, g DW Kg ${ }^{-1} \mathrm{H}_{2} \mathrm{O}$ ) of Medicago sativa and Astragalus gombiformis when 2-month old plants were subjected for 15 and 30 days (DAS) to $100 \%, 70 \%$ or $40 \%$ field capacity (FC).

Different letters above bars are significantly different at the $P=0.05$ level for the given treatment (mean $\pm 95 \%$ confidence limits, $n=4$ ). 


\section{Correlations}

As shown in Table 2, the correlation coefficients between the various studied physiological functions were analysed using linear regressions between the corresponding parameters associated two by two. Highly significant positive correlations were identified between the whole plant dry weight (DW plant ${ }^{-1}$ ) and all water relation parameters $\left(\mathrm{RWC}, \Psi_{\mathrm{w}}\right.$, WUE, and CWT) of $M$. sativa plants, when exposed to drought stress condition. The whole plant dry weight of $A$. gombiformis had a significant correlation with $\Psi_{\mathrm{w}}\left(\mathrm{R}^{2}=\right.$ $0.68)$ and CWT $\left(\mathrm{R}^{2}=0.79\right)$ but its relationship with $\mathrm{RWC}\left(\mathrm{R}^{2}=0.52\right)$ and WUE $\left(\mathrm{R}^{2}=0.44\right)$ was no significant (Table 2).

\section{Discussion}

The results from this study indicated that water deficit stress reduced the growth of both species by restricting leaf formation. In 30-days water-stressed plants with $40 \% \mathrm{FC}$, the whole plant biomass was reduced by 50.72 and $44.59 \%$ of the controls for $M$. sativa and A. gombiformis, respectively. Among these species, A. gombiformis had the reduced $\mathrm{LN}$ and it was declined by $11.76 \%$ of the controls. Our results were also in accordance with this theory. It was shown (Smit and Singels, 2006) that reducing the number of leaves is a consequence of the increase in leaf senescence and restricting leaf formation. These results are corroborated by those of Inman-Bamber and Smith (2005). In the same context, Liu and Stützel (2004) showed that reduced LN and leaf area was a drought avoidance strategy for the seedlings by reducing transpiration. Our data showed that at the end of experimental period, severe water stress significantly declined the plant height and stem elongation rate as compared to controls by 14.81 and $68.67 \%$ in $M$. sativa and by 19.91 and $36 \%$ in A. gombiformis, respectively. Similar effects were observed in other legume species such as Arachis hypogaea (Ravindra et al., 1990).

Water stress has not affected, in a similar way, the different parts of both species. Indeed, root dry weight under water limitation was less affected than shoot. These observations confirm those of Matthias and Smith (1997) and Baï and Li (2003). On the contrary, under water stress A. gombiformis developed more roots. This tendency indicated greater ability of $A$. gombiformis to adapt to moisture stress than $M$. sativa. One of the major consequences of these morphological changes is the decrease in the dry matter production of these legumes plants. Similar results were reported by Nautiyal et al. (2002) and Bhatt and Rao (2005). In accordance with this it was shown (Singh and Singh, 2006), that Dalbergia sissoo produced less roots under drought.

Water accounts for 85 to $90 \%$ on a fresh weight basis of the cell (De Raissac, 1992). The precise knowledge of the tissue water status including the leaf apparatus faces multiplicity of parameters. The utilization of leaf RWC as an indicator of the plant water status is usual. Moreover, RWC seems to have a direct physiological significance of the plant water status, in the same way as $\Psi_{\mathrm{w}}$. De Raissac (1992) showed that in the tissues, the symplasmic water section is the component that varies depending on the variation of $\Psi_{\mathrm{w}}$. The relationship is between the $\Psi_{\mathrm{w}}$ and the RWC. Our results show that the RWC decreased significantly as water stress intensified. A similar behaviour was observed in Phaseolus vulgaris (Martínez et al., 2007) and M. truncatula (Nunes et al., 2008).

Our results showed that decreasing watering regime level caused a decline in the $\Psi_{\mathrm{w}}$ in both species while observing the lowest values for the most stressed plants. The correlation coefficient between $\Psi_{\mathrm{w}}$ and RWC of both species was significantly high (Table 2) suggesting a positive relationship between these two parameters. 
M. Gorai et al.

Table 2. Correlation coefficients $\left(\mathbf{R}^{2}\right)$ between pairs of growth and water relationships parameters of Medicago sativa and Astragalus gombifrmis when 2-month old plants were subjected for 30 days to water-limited conditions.

\begin{tabular}{|c|c|c|c|c|c|c|c|c|c|c|c|c|c|c|}
\hline \multirow[b]{2}{*}{ Parameters } & \multicolumn{7}{|c|}{ M. sativa } & \multicolumn{7}{|c|}{ A. gombifrmis } \\
\hline & $\mathrm{LN}$ & SER & $\begin{array}{l}\text { Whole } \\
\text { plant DW }\end{array}$ & $\begin{array}{l}\text { Shoot } \\
\text { RGR }\end{array}$ & $\begin{array}{l}\text { Leaf } \\
\text { RWC }\end{array}$ & $\Psi_{\mathrm{w}}$ & WUE & $\mathrm{LN}$ & SER & $\begin{array}{l}\text { Whole } \\
\text { plant DW }\end{array}$ & $\begin{array}{l}\text { Shoot } \\
\text { RGR }\end{array}$ & $\begin{array}{l}\text { Leaf } \\
\text { RWC }\end{array}$ & $\Psi_{\mathrm{w}}$ & WUE \\
\hline SER & 0.64 & & & & & & & 0.71 & & & & & & \\
\hline Whole plant DW & 0.70 & 0.63 & & & & & & 0.79 & 0.66 & & & & & \\
\hline Shoot RGR & 0.80 & 0.67 & 0.96 & & & & & 0.74 & 0.66 & 0.97 & & & & \\
\hline RWC & 0.51 & 0.58 & 0.65 & 0.78 & & & & 0.23 & 0.33 & 0.52 & 0.57 & & & \\
\hline$\Psi_{\mathrm{w}}$ & 0.35 & 0.40 & 0.68 & 0.61 & 0.64 & & & 0.33 & 0.37 & 0.68 & 0.75 & 0.88 & & \\
\hline WUE & 0.54 & 0.37 & 0.89 & 0.76 & 0.41 & 0.64 & & 0.30 & 0.06 & 0.44 & 0.39 & -0.26 & 0.08 & \\
\hline CWT & 0.77 & 0.72 & 0.86 & 0.94 & 0.80 & 0.63 & 0.57 & 0.66 & 0.70 & 0.79 & 0.81 & 0.74 & 0.68 & -0.18 \\
\hline
\end{tabular}

Italic values are not significant at $P<0.05 ; \mathrm{df}(n=12) . \mathrm{LN}=$ Leaf number; $\mathrm{SER}=$ Stem elongation rate; DW $=$ Dry weight; RGR $=$ Relative growth rate; $\mathrm{RWC}=$ Relative water content; $\Psi_{\mathrm{w}}=$ Water potential; WUE $=$ Water use efficiency; CWT $=$ Cumulative water transpired. 
The former variable also had a strong relationship between these two parameters. The former variable also had a strong positive relationship with the whole plant dry weight of alfalfa (respectively, $\mathrm{R}^{2}=$ 0.68 and 0.65 , Table 2), while the whole plant dry weight of $A$. gombiformis had a significant correlation with $\Psi_{\mathrm{w}}\left(\mathrm{R}^{2}=0.68\right)$ but its relationship with RWC $\left(\mathrm{R}^{2}=0.52\right)$ was non-significant.

Our data show that decreasing watering regime caused a significant decline in transpiration rate in both species. Among the species, $A$. gombiformis showed a lower level of transpiration rate. The present data agree with findings reported on two varieties of Catharanthus roseus (Jaleel et al., 2008) and six varieties of Abelmoschus esculentus (Sankar et al., 2008). Correlation analyses revealed positive correlations between CWT and the various studied parameters, with exception of WUE in both studied legumes (Table 2). Although $M$. sativa and A. gombifomis showed a significant decline in CWT level under water limitation, these two legumes behaved differently in terms of WUE.

WUE, the functional indicator strongly related to plant growth and health under water deficit condition, is dependent on the amount of water used for growth and biomass production (Liu and Stützel, 2004; Monclus et al., 2006). Previous studies concluded that WUE decreased under water scarcity and reasoned that plants tended to use water optimally (Martín de Santa Olalla et al., 2004; Clavel et al., 2005). We observed this in $M$. sativa. Unlike alfalfa, the WUE of $A$. gombiformis plants increased as water stress intensified. The increase in this variable was mainly due to a large reduction in transpiration rate at higher water deficit levels. According to Li et al. (2003), plants having the highest WUE are the most resistant to moisture stress. It can be concluded that $A$. gombiformis plants is more tolerant to drought stress, as compared to $M$. sativa plants.

\section{Conclusions}

Medicago sativa and A. gombiformis behave differently to drought stress. Limiting water supply decreased the whole plant dry weight, SER, LN, shoot RGR, shoot/root dry weight ratio. All these morphological changes were accompanied by physiological responses which resulted in a decrease in the RWC and $\Psi_{\mathrm{w}}$. In addition, alfalfa and $A$. gombiformis could keep a high RWC. Both species decreased the CWT as water deficit stress was intensified. This correlated with a low level of the RWC especially for the more stressed plants. Both species have reacted differently in terms of WUE. Astragalus gombiformis showed more efficient than alfalfa. Hence A. gombiformis is a stress tolerant plant species that could be exploited for greening deserts and arid regions.

\section{References}

Angus, J. F. and A. F. van Herwaarden. 2001. Increasing water use and water use efficiency in dryland wheat. Agron. J. 93:290-298.

Baï, W. M. and L. H. Li. 2003. Effect of irrigation methods and quota on root water uptake and biomass of alfalfa in the Wulanbuhe sandy region of China. Agr. Water Manage. 62:139148.

Bhatt, R. M. and N. K. Rao. 2005. Influence of pod load on response of okra to water stress. Indian J. Plant Physiol. 10:54-59.

Boyer, J. S. 1982. Plant productivity and environment. Science 218:443-448.

Chaieb, M. and M. Boukhris. 1998. Flore succinte et illustrée des zones arides et sahariennes de Tunisie. Association pour la Protection de la Nature et de l'Environnement. L'Or du temps, Sfax. 
Clavel, D., N. K. Drame, H. RoyMacauley, S. Braconnier and D. Laffray. 2005. Analysis of early responses to drought associated with field drought adaptation in four Sahelian groundnut (Arachis hypogaea L.) cultivars. Environ. Exp. Bot. 54:219-230.

Cuénod, A., G. Pottier-Alapetite and A. Labbe. 1954. Flore analytique et synoptique de la Tunisie: cryptogames vasculaires, gymnospermes et monocotylédones. SEFAN, Tunis.

De Raissac, M. 1992. L'utilisation des carbohydrates de réserve et son incidence sur la production chez le riz. Agron. Trop. 46:97-105.

Hsiao, T., P. Steduto and E. Fereres. 2007. A systematic and quantitative approach to improve water use efficiency in agriculture. Irrig. Sci. 25:209-231.

Hunt, R. 1990. Basic growth analysis. Plant Growth Analysis for beginners. Unwin Hyman, London.

Inman-Bamber, N. G. and D. M. Smith. 2005. Water relations in sugarcane and response to water deficit. Field Crops Res. 92:185-202.

Jaleel, C. A., R. Gopi, B. Sankar, M. Gomathinayagam and R. Panneerselvam. 2008. Differential responses in water use efficiency in two varieties of Catharanthus roseus under drought stress. C. R. Biologies 331:42-47.

Jeon, M. W., M. B. Ali, E. J. Hahn and K. Y. Paek. 2006. Photosynthetic pigments, morphology and leaf gas exchange during ex-vitro acclimatization of micropropagated CAM Doritaenopsis plantlets under relative humidity and air temperature. Environ. Exp. Bot. 55:183-194.

Le Houérou, H. N. 1959. Recherches écologiques et floristiques sur la végétation de la Tunisie méridionale. Institut des Recherches Sahariennes, Alger.

Le Houérou, H. N. 1995. Bioclimatologie et biogéographie des steppes arides du Nord de l'Afrique. Diversité biologique, développement durable et désertisation. CIHEAM, Options méditerranéennes, Série $B$, no 10 , Montpellier, France.

Li, H.Y., W. Wang and Q.J. Ma. 2003. The osmotic adjustment and photosynthesis of a wheat cultivar Hanfeng 9703 with high yield, drought resistance under drought stress. Acta Agron. Sin. 29:759-764.

Liu, F. and H. Stützel. 2004. Biomass partitioning, specific leaf area, and water use efficiency of vegetable amaranth (Amaranthus spp.) in response to water stress. Sci. Hortic. 102:15-27.

Martín de Santa Olalla, F.J., A. Dominguez-Padilla and R. Lopez. 2004. Production and quality of onion crop (Allium cepa L.) cultivated under controlled deficit irrigation conditions in a semi-arid climate. Agr. Water Manage. 68:77-89.

Martínez, J. P., H. Silva, J. F. Ledent and M. Pinto. 2007. Effect of drought stress on the osmotic adjustment, cell wall elasticity and cell volume of six cultivars of common beans (Phaseolus vulgaris L.). Eur. J. Agron. 26:30-38.

Matthias, W. and S. E. Smith. 1997. Morphological and physiological characteristics associated with 
tolerance to summer irrigation termination in alfalfa. Crop Sci. 37:704-711.

Monclus, R., E. Dreyer, M. Villar, F. M. Delmotte, D. Delay, J. M. Petit, C. Barbaroux, D. L. Thiec, C. Bréchet and F. Brignolas. 2006. Impact of drought on productivity and water use efficiency in 29 genotypes of Populus deltoids, Populus nigra. New Phytol. 169:765-777.

Nautiyal, P. C., V. Ravindra and Y.C. Joshi. 2002. Dry matter partitioning and water use efficiency under waterdeficit during various growth stages in groundnut. Indian J. Plant Physiol. $7: 135-139$.

Nunes, C., S. S. Araújo, J. M. Silva, M. P. S. Fevereiro and A. B. Silva. 2008. Physiological responses of the legume model Medicago truncatula cv. Jemalong to water deficit. Environ. Exp. Bot. 63:289-296.

Pottier-Alapetite, G. 1979. Flore de la Tunisie. Angiosperme Dicotylédones: apétales-dialypétales-gamopétales.

Ministère de l'Enseignement Supérieur et de la Recherche Scientifique et le Ministère de l'Agriculture, Tunis.

Pottier-Alapetite, G. 1981. Flore de la Tunisie. Angiosperme Dicotylédones. Vol. II: Gamopétales. Ministère de l'Enseignement Supérieur et de la Recherche Scientifique et le Ministère de l'Agriculture, Tunis.

Radhouane, L. 2008. Caractéristiques hydriques du mil (Pennisetum glaucum (L.) R. Br.) en présence de contraintes hydriques. C. R. Biologies 331:206-214.
Ramesh, P. 2000. Effect of different levels of drought during the formtive phase on growth parameters and its relationship with dry matter accumulation in sugarecane. J. Agron. Crop Sci. 185:83-89.

Ravindra V., P. C. Nautiyal and Y. C. Joshi. 1990. Physiological analysis of drought resistance and yield in groundnut (Arachis hypogaea L.). Trop. Agric. 67:290-296.

Sankar, B., C. A. Jaleel, P. Manivannan, A. Kishorekumar, R. Somasundaram and R. Panneerselvam. 2008. Relative efficacy of water use in five varieties of Abelmoschus esculentus (L.) Moench. under water-limited conditions. Colloids Surf. B. 62:125129.

Scholander, P. F., E. D. Bradstreet, E. A. Hemmingsen and H.T. Hammel. 1965. Sap pressure in vascular plants: Negative hydrostatic pressure can be measured in plants. Science 148:339346.

Singh, B. and G. Singh. 2006. Effects of controlled irrigation on water potential, nitrogen uptake and biomass production in Dalbergia sisso seedlings. Environ. Exp. Bot. 55:209-219.

Smit, M. A. and A. Singels. 2006. The response of sugarcane canopy development to water stress. Field Crops Res. 98:91-97.

Sorrells, M. E., A. Diab and M. Nachit. 2000. Comparative genetics of drought tolerance. In: Durum Wheat Improvement in the Mediterranean Region: New Challenges. Options méditerranéennes : Série A, Séminaires méditerranéens no 40. pp. 191-201. 
M. Gorai et al.

Turner, N. C. 1986. Adaptation to water deficit: a changing perspective. Aust. J. Plant Physiol. 13:175-190.

Wright G. C., R. C. Nageswara Rao and G.D. Farquhar. 1994. Water-use efficiency and carbon isotope discrimination in peanut under water deficit conditions. Crop Sci. 34:92-97.
Wu, F., W. Baoa, F. Li and N. Wu. 2008. Effects of drought stress and $\mathrm{N}$ supply on the growth, biomass partitioning and water-use efficiency of Sophora davidii seedlings. Environ. Exp. Bot. 63:248-255. 